\title{
Thermal Polymorphism and Decomposition of $\mathrm{Y}\left(\mathrm{BH}_{4}\right)_{3}$
}

\author{
Dorthe B. Ravnsbæk, ${ }^{\dagger}$ Yaroslav Filinchuk, ${ }^{\dagger, \ddagger}$ Radovan Črný, ${ }^{\S}$ Morten B. Ley, ${ }^{\dagger}$ Dörthe Haase," \\ Hans J. Jakobsen, ${ }^{\dagger}$ Jørgen Skibsted, ${ }^{\dagger}$ and Torben R. Jensen ${ }^{\star, \dagger}$ \\ ${ }^{\dagger}$ Interdisciplinary Nanoscience Center (iNANO) and Department of Chemistry, University of Aarhus, \\ Langelandsgade 140, DK-8000 Arhus C, Denmark, ${ }^{\$}$ Swiss-Norwegian Beamlines at ESRF, BP-220, \\ 38043 Grenoble, France, ${ }^{\S}$ Laboratory of Crystallography, University of Geneva, 1211 Geneva, Switzerland, and \\ "MAX-lab, Lund University, S-22100 Lund, Sweden
}

Received November 17, 2009

\begin{abstract}
The structure and thermal decomposition of $\mathrm{Y}\left(\mathrm{BH}_{4}\right)_{3}$ is studied by in situ synchrotron radiation powder $\mathrm{X}$-ray diffraction (SR-PXD), ${ }^{11} \mathrm{~B}$ MAS NMR spectroscopy, and thermal analysis (thermogravimetric analysis/differential scanning calorimetry). The samples were prepared via a metathesis reaction between $\mathrm{LiBH}_{4}$ and $\mathrm{YCl}_{3}$ in different molar ratios mediated by ball milling. A new high temperature polymorph of $\mathrm{Y}\left(\mathrm{BH}_{4}\right)_{3}$, denoted $\beta-\mathrm{Y}\left(\mathrm{BH}_{4}\right)_{3}$, is discovered besides the $\mathrm{Y}\left(\mathrm{BH}_{4}\right)_{3}$ polymorph previously reported, denoted $\alpha-\mathrm{Y}\left(\mathrm{BH}_{4}\right)_{3} \cdot \beta-\mathrm{Y}\left(\mathrm{BH}_{4}\right)_{3}$ has a cubic crystal structure and crystallizes with the space group symmetry $P m \overline{3} m$ and a bisected a-axis, $a=5.4547(8) \AA$, as compared to $\alpha-Y\left(B H_{4}\right)_{3}, a=$ $10.7445(4) \AA(P a \overline{3}) . \beta$ - $Y\left(B_{4}\right)_{3}$ crystallizes with a regular $\mathrm{ReO}_{3}$-type structure, hence the $\mathrm{Y}^{3+}$ cations form cubes with $\mathrm{BH}_{4}{ }^{-}$anions located on the edges. This arrangement is a regular variant of the distorted $\mathrm{Y}^{3+}$ cube observed in $\alpha-Y\left(\mathrm{BH}_{4}\right)_{3}$, which is similar to the high pressure phase of $\mathrm{ReO}_{3}$. The new phase, $\beta-Y\left(\mathrm{BH}_{4}\right)_{3}$ is formed in small amounts during ball milling; however, larger amounts are formed under moderate hydrogen pressure via a phase transition from $\alpha$ - to $\beta$-Y $\left(\mathrm{BH}_{4}\right)_{3}$, at $\sim 180^{\circ} \mathrm{C}$. Upon further heating, $\beta$ - $\mathrm{Y}\left(\mathrm{BH}_{4}\right)_{3}$ decomposes at $\sim 190^{\circ} \mathrm{C}$ to $\mathrm{YH}_{3}$, which transforms to $\mathrm{YH}_{2}$ at $270^{\circ} \mathrm{C}$. An unidentified compound is observed in the temperature range $215-280^{\circ} \mathrm{C}$, which may be a new $\mathrm{Y}-\mathrm{B}-\mathrm{H}$ containing decomposition product. The final decomposition product is $\mathrm{YB}_{4}$. These results show that boron remains in the solid phase when $\mathrm{Y}\left(\mathrm{BH}_{4}\right)_{3}$ decomposes in a hydrogen atmosphere and that $\mathrm{Y}\left(\mathrm{BH}_{4}\right)_{3}$ may store hydrogen reversibly.
\end{abstract}

\section{Introduction}

The transition toward a sustainable and environmentally friendly energy system capable of meeting the increasing energy demands is considered one of the greatest challenges in the 21st century. Hydrogen is suggested as a future carrier of renewable energy, but a safe, compact and efficient hydrogen storage method still remains to be identified. ${ }^{1-3}$ Borohydride-based materials currently receive increasing interest as potential hydrogen storage systems because of their high theoretical hydrogen densities. Unfortunately, many of the well-known borohydrides exhibits poor thermodynamic and

*To whom correspondence should be addressed.E-mail: trj@chem.au.dk. Phone: +458942 3894. Fax: +45 86196199

(1) Schlapbach, L.; Züttel, A. Nature 2001, 414, 353-358.

(2) Schlapbach, L. Nature 2009, 460, 809-811.

(3) Ritter, J. A.; Ebner, A. D.; Wang, J.; Zidan, R. Mater. Today 2003, Sept, $18-23$.

(4) Grochala, W.; Edwards, P. P. Chem. Rev. 2004, 104, 1283-1315.

(5) Orimo, S.; Nakamori, Y.; Eliseo, J. R.; Zuttel, A.; Jensen, C. M. Chem Rev. 2007, 107, 4111-4132.

(6) Filinchuk, Y.; Chernyshov, D.; Dmitriev, V. Z. Kristallogr. 2008, 223, 649-659. kinetic properties, which hamper their utilization in technological applications. ${ }^{4-6}$

Recently, several new mixed-metal borohydrides have been synthesized and characterized, and some of these have improved thermodynamic and kinetic properties, for example, $\mathrm{LiSc}\left(\mathrm{BH}_{4}\right)_{4}$ and $\mathrm{NaSc}\left(\mathrm{BH}_{4}\right)_{4}$ are found to decompose in the temperature ranges 140 to $260^{\circ} \mathrm{C}$ and 167 to $267{ }^{\circ} \mathrm{C}$, respectively. ${ }^{7,8}$ These are significantly lower temperatures as compared to the corresponding ones for the alkali borohydrides, $\mathrm{LiBH}_{4}$ and $\mathrm{NaBH}_{4}$, which decompose at approximately 380 and $400{ }^{\circ} \mathrm{C}$, respectively.

Furthermore, recent studies of metal borohydrides reveal a remarkable diversity in the structural topologies, for example, the compounds $\mathrm{LiZn}_{2}\left(\mathrm{BH}_{4}\right)_{5}$ and $\mathrm{NaZn}_{2}\left(\mathrm{BH}_{4}\right)_{5}$ are built

(7) Hagemann, H.; Longhini, M.; Kaminski, J. W.; Wesolowski, T. A.; Črný, R.; Penin, N.; Sørby, M. H.; Hauback, B. C.; Severa, G.; Jensen, C. M. J. Phys. Chem. A 2008, 112, 7551-7555.

(8) Cerný, R.; Severa, G.; Ravnsbæk, D. B.; Filinchuk, Y.; d'Anna, V.; Hagemann, H.; Haase, D.; Jensen, C. M.; Jensen, T. R. J. Phys. Chem. C 2010, 114, 1357-1364.

(9) Züttel, A.; Rentsch, S.; Fischer, P.; Wenger, P.; Sudan, P.; Mauron,

Ph.; Emmenegger, Ch. J. Alloys Compd. 2003, 356-357, 515-520. 
from two identical interpenetrated three-dimensional frameworks consisting of isolated complex anions, $\left[\mathrm{Zn}_{2}\left(\mathrm{BH}_{4}\right)_{5}\right]^{-}$, whereas $\mathrm{NaZn}\left(\mathrm{BH}_{4}\right)_{3}$ consists only of a single three-dimensional network containing polymeric anions of $\left[\mathrm{Zn}\left(\mathrm{BH}_{4}\right)_{3}\right]_{n}{ }^{n-} \cdot{ }^{10}$ Isolated complex anions have also been observed in other structures, such as $\left[\mathrm{Sc}\left(\mathrm{BH}_{4}\right)_{4}\right]^{-}$in $M \mathrm{Sc}\left(\mathrm{BH}_{4}\right)_{4}(M=\mathrm{Li}$ or $\mathrm{Na})$ or $[\mathrm{Zn}$ $\left.\left(\mathrm{BH}_{4}\right) \mathrm{Cl}_{2}\right]^{-}$in the heteroleptic borohydride, $\mathrm{KZn}\left(\mathrm{BH}_{4}\right) \mathrm{Cl}_{2}{ }^{7,8,11}$ Thus, studies of structural, physical, and chemical properties of novel metal borohydrides may hold the key to gain further insight and tailor the stability and property of borohydrides.

Besides the thermodynamic and kinetic properties, it is also of vital importance for possible applications of borohydrides as reversible hydrogen carriers to address the chemical decomposition reactions. For some metal borohydrides a release of gaseous boranes such as diborane has been observed, which hampers reversible hydrogen storage. ${ }^{12,13}$ Therefore, formation of metal borides during decomposition is an important indication of possible reversibility, since boron is kept in the solid state. Furthermore, formation of metal borides is preferred to formation of elemental boron because of the high stability of the latter. It appears that formation of metal borides is facilitated by a hydrogen partial pressure of 1 to 5 bar, which is also the working conditions in most possible applications. ${ }^{14}$ Therefore, synthesis, structural characterization, and studies of physical and chemical properties of new metal borohydrides may open new routes for design and preparation of hydrogen storage materials, potentially with improved thermodynamic and kinetic properties for hydrogen release and uptake.

Here we report on the synthesis, characterization, and thermal decomposition of $\mathrm{Y}\left(\mathrm{BH}_{4}\right)_{3}$, studied by in situ synchrotron radiation powder X-ray diffraction (SR-PXD), ${ }^{11} \mathrm{~B}$ magic-angle spinning (MAS) NMR, thermogravimetric analysis (TGA), and differential scanning calorimetry (DSC). Furthermore, we present the crystal structure of a new $\mathrm{Y}\left(\mathrm{BH}_{4}\right)_{3}$ phase denoted $\beta-\mathrm{Y}\left(\mathrm{BH}_{4}\right)_{3}$.

\section{Experimental Section}

Synthesis. Anhydrous yttrium chloride, $\mathrm{YCl}_{3}$ (SigmaAldrich, 99.99\%) and lithium borohydride, $\mathrm{LiBH}_{4}$ (SigmaAldrich, 98\%) were mixed in the molar ratios 1:3 and 1:4, and ball-milled (BM) 120 min under inert conditions (argon atmosphere) in a Fritsch Pulverisette planetary mill using 80 $\mathrm{mL}$ tungsten carbide steel containers and approximately an 1:35 mass ratio of sample to balls (o.d. $10 \mathrm{~mm}$, tungsten carbide).

To study the decomposition product, a ball milled sample of $\mathrm{LiBH}_{4}$ and $\mathrm{YCl}_{3}$ (4:1) was mounted in a corundum crucible placed inside a sealed argon filled quartz capillary, and heated in a furnace from room temperature (RT) to $500^{\circ} \mathrm{C}$ with a heating rate of $7^{\circ} \mathrm{C} /$ min and then kept at a fixed temperature of $500{ }^{\circ} \mathrm{C}$ for $90 \mathrm{~min}$.

The preparation and manipulation of all samples were performed in an argon-filled glovebox with a circulation purifier $\left(p\left(\mathrm{O}_{2}, \mathrm{H}_{2} \mathrm{O}\right)<0.1 \mathrm{ppm}\right)$.

(10) Ravnsbæk, D.; Filinchuk, Y.; Cerenius, Y.; Jakobsen, H. J.; Besenbacher, F.; Skibsted, J.; Jensen, T. R. Angew. Chem., Int. Ed. 2009, 48, 66596663

(11) Ravnsbæk, D. B.; Sørensen, L. H.; Filinchuk, Y.; Reed, D.; Book, D.; Cerenius, Y.; Jakobsen, H. J.; Besenbacher, F.; Skibsted, J.; Jensen, T. R. Eur. J. Inorg. Chem. 2010, DOI: 10.1002/ejic.201000119.

(12) Nakamori, Y.; Li, H. -W.; Kikuchi, K.; Aoki, M.; Miwa, K.; Towata, S.; Orimo, S. J. Alloys Compd. 2007, 446-447, 296-300.

(13) Kostka, J.; Lohstroh, W.; Fichtner, M.; Hahn, H. J. Phys. Chem. C 2007, 111, 14026-14029.

(14) Bosenberg, U.; Doppiu, S.; Mosegaard, L.; Barkhordarian, G.; Eigen, N.; Borgschulte, A.; Jensen, T. R.; Cerenius, Y.; Gutfleisch, O.; Klassen, T.; Dornheim, M.; Bormann, R. Acta Mater. 2007, 55, 3951-3958.
Laboratory X-ray Powder Diffraction. All samples were initially investigated using laboratory powder X-ray diffraction (PXD) to identify the reaction products and estimate the crystallinity of the samples. PXD measurements were performed in Debye-Scherrer transmission geometry using a Stoe diffractometer equipped with a curved $\mathrm{Ge}(111)$ monochromator $\left(\mathrm{Cu} \mathrm{K} \alpha_{1}\right.$ radiation, $\lambda=1.54060 \AA)$ and a curved position sensitive detector. Data were collected at RT between 4 and $127^{\circ} 2 \theta$ with counting times of $\sim 960$ s per step. Air-sensitive samples were mounted in a glovebox in $0.5 \mathrm{~mm}$ glass capillaries sealed with glue.

In Situ Time-Resolved SR-PXD. One set of in situ timeresolved SR-PXD data was collected at beamline I911-5 of the synchrotron MAX II, Lund, Sweden in the research laboratory MAX-Lab with a MAR165 CCD detector system and a selected wavelength of $\lambda=0.9077 \AA .{ }^{15}$ The X-ray exposure time was $30 \mathrm{~s}$. The sample cell was specially developed for studies of gas/ solid reactions and allows high pressure and temperature to be applied. The powdered sample was mounted in a sapphire $\left(\mathrm{Al}_{2} \mathrm{O}_{3}\right)$ single-crystal tube (o.d. $1.09 \mathrm{~mm}$, i.d. $\left.0.79 \mathrm{~mm}\right)$ in an argon-filled glovebox $\left(p\left(\mathrm{O}_{2}, \mathrm{H}_{2} \mathrm{O}\right)<1 \mathrm{ppm}\right)$. The sample holder was sealed in a glovebox. The temperature was controlled with a thermocouple placed in the sapphire tube $1 \mathrm{~mm}$ from the sample. ${ }^{16,17}$ The sample was heated from RT to $500{ }^{\circ} \mathrm{C}$ with a heating rate of $7^{\circ} \mathrm{C} / \mathrm{min}$.

Another set of SR-PXD data was collected the Swiss-Norwegian Beamlines (SNBL) at the European Synchrotron Radiation Facility (ESRF) in Grenoble, France. A glass capillary (o.d. $0.5 \mathrm{~mm}$ ) with the sample was heated from RT to $500^{\circ} \mathrm{C}$ at a rate of $4{ }^{\circ} \mathrm{C} / \mathrm{min}$, while SR-PXD data were collected. The temperature was controlled with a Cyberstar hot air blower. The data were collected using a MAR345 image plate detector at a sample to detector distance of $275 \mathrm{~mm}$, and a selected X-ray wavelengths of $\lambda=0.822406 \AA$. The capillary was oscillated by $20^{\circ}$ during exposure of the sample to the X-ray beam for $20 \mathrm{~s}$.

All obtained raw images were transformed to 2D-powder patterns using the FIT2D program, ${ }^{18}$ and calibration measurements of the standard NIST $\mathrm{LaB}_{6}$ sample, masking diffraction spots from the single-crystal sapphire sample holder. Uncertainties of the integrated intensities were calculated at each $2 \theta$-point by applying Poisson statistics to the intensity data, considering the geometry of the detector. ${ }^{19}$

Structure Solution of a New $\mathbf{Y}\left(\mathrm{BH}_{4}\right)_{3}$ Polymorph. Data collected at I911-5, MAX II on the $\mathrm{LiBH}_{4}-\mathrm{YCl}_{3}(4: 1)$ sample at $\sim 180^{\circ} \mathrm{C}$, containing the high-temperature $\beta$ - $\mathrm{Y}\left(\mathrm{BH}_{4}\right)_{3}$ phase and no trace of the low-temperature $\alpha$-polymorph, was used for indexing and structure solution. Diffraction peaks were indexed by the program $\operatorname{Dicvol}^{20}$ in a primitive cubic cell with no systematic absences. Thus, the structure solution was attempted in the space group $\operatorname{Pm} \overline{3} m$. The structure was solved in this space group by global optimization in direct space using the program $\mathrm{FOX},{ }^{21}$ varying one yttrium position and the orientation of the rigid tetrahedral $\mathrm{BH}_{4}$ group $(\mathrm{B}-\mathrm{H}$ distance fixed at $1.22 \AA$ ).

The yttrium atom is found at the special position $0,0,0$ and boron in the $\mathrm{BH}_{4}$ group at $1 / 2,0,0$, thus adopting the structure of the ambient pressure polymorph of $\mathrm{ReO}_{3}{ }^{22}$ The orientation

(15) Mammen, C. B.; Ursby, T.; Cerenius, Y.; Thunnissen, M.; AlsNielsen, J.; Larsen, S.; Liljas, A. Acta Phys. Pol., A 2002, 101, 595-602.

(16) Clausen, B. S.; Steffensen, G.; Fabius, B.; Villadsen, J.; Feidenhans'1, R.; Topsøe, H. J. Catal. 1991, 132, 524-535.

(17) Ravnsbæk, D.; Mosegaard, L.; Jørgensen, J. E.; Jensen, T. R. Proceedings of the 29th Risø International Symposium on Materials Science: Energy Materials-Advances in Characterization, Modelling and Application, July 15, 2008, Roskilde, Denmark.

(18) Hammersley, A. P.; Svensson, S. O.; Hanfland, M.; Fitch, A. N.; Häusermann, D. High Pressure Res. 1996, 14, 235-248.

(19) Vogel, S.; Ehm, L.; Knorr, K.; Braun, G. Adv. X-ray Anal. 2002, 45 , 31

(20) Boultif, A.; Louer, D. J. Appl. Crystallogr. 2004, 37, 724.

(21) Favre-Nicolin, V.; Cerný, R. J. Appl. Crystallogr. 2002, 35, 734.

(22) Meisel, K. Z. Anorg. Allg. Chem. 1932, 207, 121-128. 

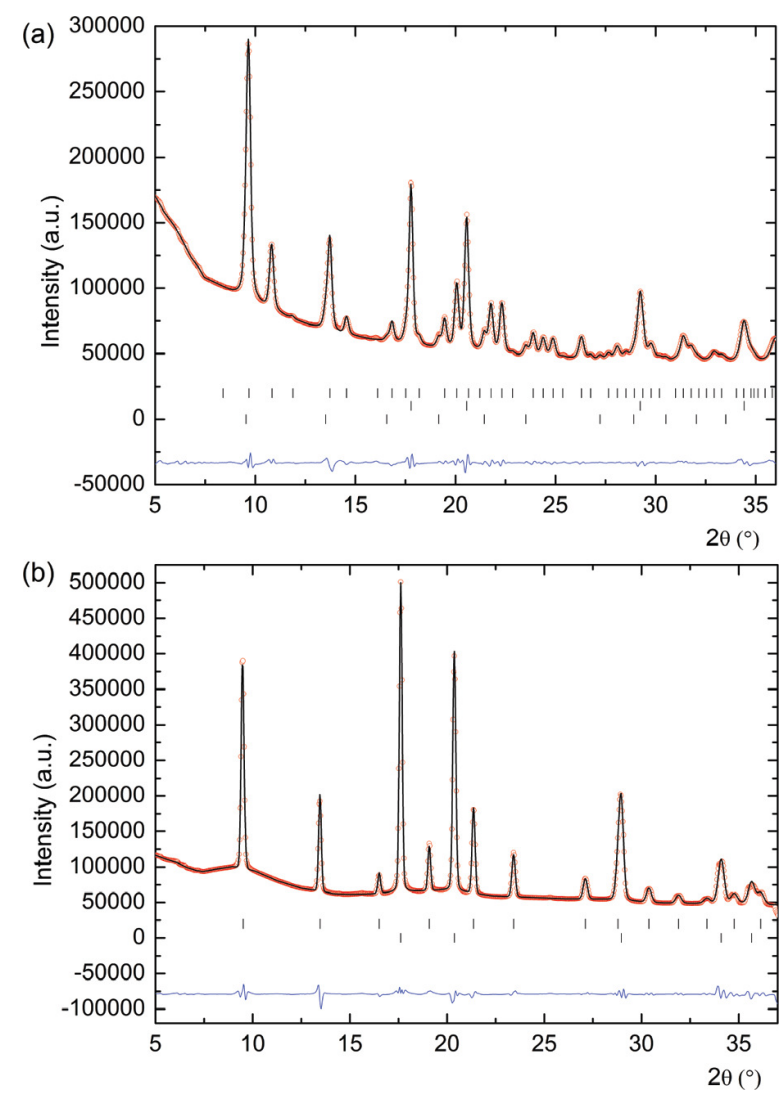

Figure 1. Rietveld plot for the sample of $\mathrm{LiBH}_{4}-\mathrm{YCl}_{3}(4: 1)$ measured at (a) RT and (b) $180^{\circ} \mathrm{C}$. At RT the sample contains a mixture of $\alpha-Y\left(\mathrm{BH}_{4}\right)_{3}$ (top), $\beta-\mathrm{Y}\left(\mathrm{BH}_{4}\right)_{3}$ (bottom), and $\mathrm{LiCl}$ (middle), whereas the phase transition $\alpha$ - to $\beta$-Y $\left(\mathrm{BH}_{4}\right)_{3}$ has occurred at $180^{\circ} \mathrm{C}$ and only $\beta$-Y $\left(\mathrm{BH}_{4}\right)_{3}$ (top) and $\mathrm{LiCl}$ (bottom) is present.

of the $\mathrm{BH}_{4}$ group, however, allows two possibilities: one with hydrogen position at the $24 m$ Wyckoff site $x=0.62910, y=$ $0.12910, z=-0.12910$ and the other with hydrogen position at the 24k Wyckoff site $x=0.37095, y=0, z=0.18260$. The first results in a frustrated net of short $(1.86 \AA) \mathrm{H} \cdots \mathrm{H}$ contacts, which cannot be completely avoided in any, even locally ordered, structure. The second possibility also brings to a net of repulsive $(1.45 \AA) \mathrm{H} \cdot \cdot \mathrm{H}$ contacts; however, it allows a locally ordered structure to be built with no $\mathrm{H} \cdots \mathrm{H}_{\circ}$ distances between neighboring $\mathrm{BH}_{4}$ groups shorter than $2.48 \AA$. Without distortion or cell doubling, only two subgroups of $P m \overline{3} m$, namely, $P m \overline{3}$ and $P 23$ allows $\mathrm{BH}_{4}$ tetrahedra with periodically ordered $\mathrm{H}$-atoms in the $24 k$ Wyckoff site. However, the $\mathrm{BH}_{4}$ group in the ordered structures would have a square-planar geometry. Thus, it was finally concluded that $\beta-\mathrm{Y}\left(\mathrm{BH}_{4}\right)_{3}$ has the $P m \overline{3} m$ structure with $\mathrm{BH}_{4}$ group disordered over two positions.

The final refinement was performed by the Rietveld method using the program Fullprof. ${ }^{23}$ The background was described by linear interpolation between selected points. Only one structural parameter was refined; an overall isotropic atomic displacement, resulting in the excellent refinement factors, $R_{\mathrm{B}}=$ $2.6 \%, R_{\mathrm{F}}=1.9 \%, R_{\mathrm{p}}=1.4 \%, R_{\mathrm{wp}}=2.6 \%$ (not corrected for background), and $R_{\mathrm{p}}=8.4 \%, R_{\mathrm{wp}}=8.3 \%$ (corrected for background) and $\chi^{2}=1780$ (this value is high because of the very high counting statistics accumulated by the $2 \mathrm{D}$ detector). The Rietveld refinement profile of diffraction from $\mathrm{LiCl}$ and $\beta$-Y $\left(\mathrm{BH}_{4}\right)_{3}$ is shown in Figure $1 \mathrm{~b}\left(\right.$ data measured at $\left.180^{\circ} \mathrm{C}\right)$ and for a sample containing $\mathrm{LiCl}, \alpha-$ and $\beta-\mathrm{Y}\left(\mathrm{BH}_{4}\right)_{3}$ in Figure 1a (data measured at RT).

(23) Rodrigues-Carvajal, J. Physica B 1993, 192, 55.
The sequential refinement in Fullprof was used to refine the cell parameters and weight fractions of the two $\mathrm{Y}\left(\mathrm{BH}_{4}\right)_{3}$ polymorphs against the temperature-resolved in situ SR-PXD data.

${ }^{11}$ B MAS NMR. Solid-state ${ }^{11} \mathrm{~B}$ MAS NMR spectra were obtained on a Varian INOVA-300 (7.05 T), INOVA-400 (9.39 T), and Direct Drive VNMRS-600 (14.09 T) spectrometers using home-built $\mathrm{CP} / \mathrm{MAS}$ NMR probes for $5 \mathrm{~mm}$ and $4 \mathrm{~mm}$ outer diameter rotors. The experiments employed a $0.5 \mu \mathrm{s}$ excitation pulse for ${ }^{11} \mathrm{~B}$ rf field strengths of $\gamma \mathrm{B}_{1} / 2 \pi \approx 70 \mathrm{kHz}$. The spectra of the $\mathrm{Y}\left(\mathrm{BH}_{4}\right)_{3}$ samples employed ${ }^{1} \mathrm{H}$ decoupling $\left(\gamma \mathrm{B}_{2} / 2 \pi \approx 100 \mathrm{kHz}\right)$ during acquisition. The NMR experiments were performed at ambient temperatures using airtight endcapped zirconia rotors, which were packed with the samples in an Ar-filled glovebox. Isotropic chemical shifts are relative to neat $\mathrm{F}_{3} \mathrm{~B} \cdot \mathrm{O}\left(\mathrm{CH}_{2} \mathrm{CH}_{3}\right)_{2}$, employing a $0.1 \mathrm{M} \mathrm{H}_{3} \mathrm{BO}_{3}$ aqueous solution $\left(\delta_{\text {iso }}=19.6 \mathrm{ppm}\right)$ as a secondary, external standard sample. Simulations of the MAS NMR spectra were performed using the STARS software package. ${ }^{24}$

Thermal Analysis. Simultaneous TGA and DSC were performed using a Netzsch STA449C Jupiter instrument heated from RT to $500{ }^{\circ} \mathrm{C}, \Delta T / \Delta t=7$ or $10{ }^{\circ} \mathrm{C} / \mathrm{min}$ using corundum crucibles with lid as sample holder. The experiments were conducted in helium (4.6) atmosphere.

\section{Results and Discussion}

Synthesis and Initial Phase Analysis. Ball milling (BM) cause a metathesis reaction between $\mathrm{LiBH}_{4}$ and $\mathrm{YCl}_{3}$, which results in formation of $\mathrm{Y}\left(\mathrm{BH}_{4}\right)_{3}$ and $\mathrm{LiCl}$ according to eq 1 .

$$
3 \mathrm{LiBH}_{4}+\mathrm{YCl}_{3} \rightarrow \mathrm{Y}\left(\mathrm{BH}_{4}\right)_{3}+3 \mathrm{LiCl}
$$

The polymorph $\alpha-\mathrm{Y}\left(\mathrm{BH}_{4}\right)_{3}$, previously obtained from diethyl ether solutions of $\mathrm{LiBH}_{4}$ and $\mathrm{YCl}_{3}$ at RT and also by $\mathrm{BM}$, is obtained. ${ }^{25-27}$ However, small amounts of a new polymorph of $\mathrm{Y}\left(\mathrm{BH}_{4}\right)_{3}$, denoted $\beta-\mathrm{Y}\left(\mathrm{BH}_{4}\right)_{3}$, are also formed by BM (see Figure 1a). $\alpha-Y\left(\mathrm{BH}_{4}\right)_{3}$ can be considered as the stable phase at ambient conditions, whereas $\beta-\mathrm{Y}\left(\mathrm{BH}_{4}\right)_{3}$ is a high temperature polymorph that can be quenched and is in fact metastable at room temperature. This is similar to the high temperature phases of $\mathrm{Mg}\left(\mathrm{BH}_{4}\right)_{2}$ (space group $F d d d$ ) and $\mathrm{Ca}\left(\mathrm{BH}_{4}\right)_{2}$ (space group $P \overrightarrow{4}$ ), which can also be quenched to room temperature. ${ }^{28,29}$

The fact that the simple metathesis reaction occurs in the mechano-chemical synthesis of $\mathrm{Y}\left(\mathrm{BH}_{4}\right)_{3}$ is in contrast to the synthesis of $\mathrm{LiSc}\left(\mathrm{BH}_{4}\right)_{4}$ and $\mathrm{NaSc}\left(\mathrm{BH}_{4}\right)_{4}$, where the mixed-metal borohydrides are formed. ${ }^{7,8}$ It is noteworthy, that scandium and yttrium chlorides react differently even though they are both rare earth ions and have the same charge. However, the difference in ionic radii between that of $\operatorname{Sc}^{3+}(0.75 \AA)$ and that of $\mathrm{Y}^{3+}(0.90 \AA)$ might explain this difference in the reaction pathway, that is, the radius of $\mathrm{Sc}^{3+}$ is similar to that of $\mathrm{Li}^{+}(0.76 \AA)$,

(24) Skibsted, J.; Nielsen, N. C.; Bildsøe, H.; Jakobsen, H. J. J. Magn. Reson. 1991, 95, 88-117.

(25) Sato, T.; Miwa, K.; Nakamori, Y.; Ohoyama, K.; Li, H. -W.; Noritake, T.; Aoki, M.; Towata, S. -I.; Orimo, S.-I. Phys. Rev. B 2008, 77, 104114.

(26) Yan, Y.; Li, H.-W.; Sato, T.; Umeda, N.; Miwa, K.; Towata, S.-I.; Orimo, S.-I. Int. J. Hydrogen Energy 2009, 34, 5732-5736.

(27) Jaroń, T.; Grochala, W. Dalton Trans. 2010, 39, 160-166.

(28) Her, J. -H.; Stephens, P. W.; Gao, Y.; Soloveichik, G. L.; Rijssenbeek, J.; Andrus, M.; Zhao, J. -C. Acta Crystallogr., Sect. B. 2007, 63, 561568 .

(29) Filinchuk, Y.; Rönnebro, E.; Chandra, D. Acta Mater. 2009, 57, 732- 
Table 1. Structural Data, Hydrogen Content, Volume Per Formula Unit, and Density for $\alpha$ - and $\beta$-Y $\left(\mathrm{BH}_{4}\right)_{3}$

\begin{tabular}{ccccccc}
\hline phase & space group & $a[\AA]$ & $Z$ & $V / Z\left[\AA^{3}\right]$ & $\rho\left[\mathrm{g} \mathrm{cm}^{-3}\right]$ & $\left.\rho_{\mathrm{v}}\left(\mathrm{H}_{2}\right)\left[\mathrm{kg} \mathrm{H}_{2} \mathrm{~m}^{-3}\right)\right]$ \\
\hline$\alpha-\mathrm{Y}\left(\mathrm{BH}_{4}\right)_{3}$ & $P a \overline{3}$ & $10.7445(4)$ & 8 & 155.2 & 1.43 & 129.7 \\
$\beta-\mathrm{Y}\left(\mathrm{BH}_{4}\right)_{3}$ & $P m \overline{3} m$ & $5.4547(8)$ & 1 & 161.5 & 1.36 & 9.07 \\
& & & & 123.4
\end{tabular}

whereas that of $\mathrm{Y}^{3+}$ is significantly larger; ${ }^{30}$ hence, the coordination of the $\mathrm{BH}_{4}{ }^{-}$ligand is likely to change.

For the ball milled sample $\mathrm{LiBH}_{4}-\mathrm{YCl}_{3}(4: 1)$ used in this study, no diffraction from the starting compounds is observed by PXD, and from Rietveld refinement the sample composition is found to be $40 \mathrm{wt} \% \alpha-\mathrm{Y}\left(\mathrm{BH}_{4}\right)_{3}$, 10 wt $\% \beta-\mathrm{Y}\left(\mathrm{BH}_{4}\right)_{3}$, and $50 \mathrm{wt} \% \mathrm{LiCl}$. However, for the sample with the 3:1 composition, both reactants, $\mathrm{LiBH}_{4}$ and $\mathrm{YCl}_{3}$, are observed in the milled mixtures by PXD, corresponding to 15 and $30 \mathrm{wt} \%$, respectively, indicating that the metathesis reaction for this composition was not completed under the selected conditions of the $\mathrm{BM}$, which yielded 25 wt $\% \alpha-\mathrm{Y}\left(\mathrm{BH}_{4}\right)_{3}, 4$ wt $\% \beta-\mathrm{Y}\left(\mathrm{BH}_{4}\right)_{3}$, and 26 wt $\% \mathrm{LiCl}$. For the sample with the $3: 1$ composition this result was found to be highly reproducible, whereas the amount of reactants found in the ball milled sample $\mathrm{LiBH}_{4}-\mathrm{YCl}_{3}(4: 1)$ varied slightly among the samples.

Comparison of $\alpha-\mathrm{Y}\left(\mathrm{BH}_{4}\right)_{3}$ and $\beta-\mathrm{Y}\left(\mathrm{BH}_{4}\right)_{3}$ Crystal Structures. The crystal structure of the low-temperature $\alpha-\mathrm{Y}\left(\mathrm{BH}_{4}\right)_{3}$ phase is cubic; space group $P a \overline{3}$ and cell parameter $a=10.7445(4) \AA$ at RT (see Table 1), in agreement with the previous report. ${ }^{25}$ The arrangement of the $\mathrm{Y}^{3+}$ and $\mathrm{BH}_{4}{ }^{-}$ions is that of a distorted $\mathrm{ReO}_{3}$-type structure, where the $\mathrm{BH}_{4}{ }^{-}$anions are located on the edges of a distorted $\mathrm{Y}^{3+}$ cube (see Figure 2a). The mode of $\mathrm{BH}_{4}{ }^{-}$coordination by $\mathrm{Y}^{3+}$ cations can be determined from the synchrotron X-ray diffraction data only tentatively; however, it is consistent with the model obtained from the neutron diffraction data. ${ }^{25}$ The coordination mode for the $\mathrm{BH}_{4}{ }^{-}$anion to yttrium corresponds to the cation $\cdots \mathrm{H}_{2} \mathrm{~B}$ coordination scheme, that is, the $\mathrm{BH}_{4}^{-}$ anion has an edge of two $\mathrm{H}$-atoms oriented toward the cation. It results in a 12-fold coordination of yttrium to hydrogen or, equivalently, a 6-fold coordination of $\mathrm{Y}$ to $\eta^{2}-\mathrm{BH}_{4}{ }^{-}$. The nearly linear coordination of the $\mathrm{BH}_{4}$ group via the opposite edges is typical in borohydrides, such as $\mathrm{Be}\left(\mathrm{BH}_{4}\right)_{2},{ }^{31} \mathrm{Mg}\left(\mathrm{BH}_{4}\right)_{2},{ }^{32}$ and $\mathrm{Mn}\left(\mathrm{BH}_{4}\right)_{2}$. ${ }^{33}$

The new high-temperature $\beta$-Y $\left(\mathrm{BH}_{4}\right)_{3}$ phase also exhibits a cubic crystal structure, with an $a$-axis approximately half as large and in the space group $P m \overline{3} m$ (see Table 1). In fact, the structures of $\alpha-\mathrm{Y}\left(\mathrm{BH}_{4}\right)_{3}$ and $\beta$-Y $\left(\mathrm{BH}_{4}\right)_{3}$ are closely related. The structure of $\beta-\mathrm{Y}\left(\mathrm{BH}_{4}\right)_{3}$ has a regular $\mathrm{ReO}_{3}$-type, ${ }^{22}$ hence, the $\mathrm{Y}^{3+}$ cations form a cube with $\mathrm{BH}_{4}{ }^{-}$anions located on the edges (see Figure 2b). This arrangement is a regular variant of the distorted $\mathrm{Y}^{3+}$ cube observed in $\alpha-\mathrm{Y}\left(\mathrm{BH}_{4}\right)_{3}$, which is comparable to the high pressure phase of $\mathrm{ReO}_{3},{ }^{34}$ which shows also a $2 \times 2 \times 2$ cubic superstructure (space group $\operatorname{Im} \overline{3})$, however, with a regular $\mathrm{Re}^{6+}$ cube and tilted $\mathrm{ReO}_{6}$

(30) CRC Handbook of Chemistry and Physics, 88th ed.; Lide, D. R., Ed.; CRC Press: Boca Raton, FL, 2007; pp 12-18.

(31) Marynick, D. S.; Lipscomb, W. N. Inorg. Chem. 1972, 11, 820-823.

(32) Filinchuk, Y.; Cerný, R.; Hagemann, H. Chem. Mater. 2009, 21, $925-$ 933.

(33) Černý, R.; Penin, N.; Hagemann, H.; Filinchuk, Y. J. Phys. Chem. C 2009, 113, 9003-9007.

(34) Schirber, J. E.; Morosin, B.; Alkire, R. W.; Larson, A. C.; Vergamini, P. J. Phys. Rev. B: Condens. Matter 1984, 29, 4150-4152.
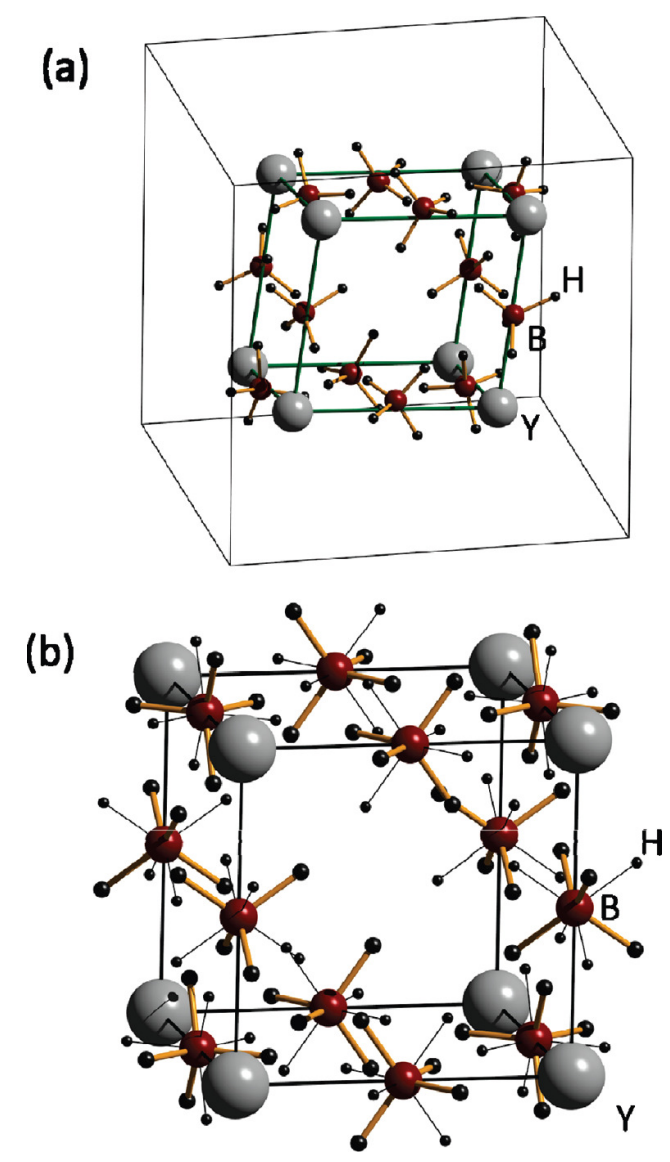

Figure 2. Crystal structure of (a) the low-temperature $\alpha-\mathrm{Y}\left(\mathrm{BH}_{4}\right)_{3}$ phase and (b) the high-temperature $\beta$ - $\mathrm{Y}\left(\mathrm{BH}_{4}\right)_{3}$ phase. Two orientations of the disordered $\mathrm{BH}_{4}$ group in the latter structure are depicted by bold and thin lines: a possible local ordering of the $\mathrm{BH}_{4}$ groups, avoiding $\mathrm{H} \cdots \mathrm{H}$ distances shorter than $2.48 \AA$, is shown.

octahedra. This means that the octahedral coordination of the $\mathrm{Y}^{3+}$ cations to six $\mathrm{BH}_{4}^{-}$anions is ideal in $\beta$ - $\mathrm{Y}\left(\mathrm{BH}_{4}\right)_{3}$ with 6 identical $\mathrm{Y}-\mathrm{B}$ distances of 2.7274(4) $\AA$ at RT (versus 2.714(11) and 2.732(11) $\AA$ in the $\alpha$-phase), 3 identical $\mathrm{B}-\mathrm{Y}-\mathrm{B}$ angles of $180^{\circ}$, and $12 \mathrm{~B}-\mathrm{Y}-\mathrm{B}$ angles of $90^{\circ}$ (versus $168.82(3)^{\circ}$ and $78.32(3)-104.31(4)^{\circ}$, respectively, in the $\alpha$-phase). The connection between the $\mathrm{YB}_{6}$ octahedra via the corner sharing also gives rise to ideal $\mathrm{Y}-\mathrm{B}-\mathrm{Y}$ angles of $180^{\circ}$ in the $\beta-\mathrm{Y}\left(\mathrm{BH}_{4}\right)_{3}$ structure (168.82(3) $)^{\circ}$ in the $\alpha$-phase).

It is noteworthy, that yttrium atoms in the $\alpha$ - and $\beta$-Y $\left(\mathrm{BH}_{4}\right)_{3}$ structures have the same coordination number $(\mathrm{CN}=12)$ with respect to the hydrogen atoms as scandium in the recently discovered $M \mathrm{Sc}\left(\mathrm{BH}_{4}\right)_{4}(M=\mathrm{Li}$ or $\mathrm{Na}$ ) series of borohydrides, ${ }^{7,8}$ despite the difference in ionic radii of $\mathrm{Y}^{3+}$ and $\mathrm{Sc}^{3+}$. However, the number of the $\mathrm{BH}_{4}$ units coordinated by the metal atoms and the $\mathrm{M} \cdot \mathrm{BH}_{4}$ coordination modes are very different: in $M$ Sc$\left(\mathrm{BH}_{4}\right)_{4}(M=\mathrm{Li}$ and $\mathrm{Na})$ four $\mathrm{BH}_{4}{ }^{-}$anions are coordinated by $\mathrm{Sc}$ via the faces, that is, cation $\cdots \mathrm{H}_{3} \mathrm{~B}$ coordination scheme or, equivalently, 4-fold $\mathrm{Sc}$ to 
$\eta^{3}-\mathrm{BH}_{4}{ }^{-}$coordination. Hydrogen forms a distorted cuboctahedron around $\mathrm{Sc}^{3+}$ cations in the $M \mathrm{Sc}\left(\mathrm{BH}_{4}\right)_{4}$ $(M=\mathrm{Li}$ or $\mathrm{Na})$ stuctures, ${ }^{7,8}$ while in both the $\alpha$ - and $\beta$-Y $\left(\mathrm{BH}_{4}\right)_{3}$ structures six $\mathrm{BH}_{4}{ }^{-}$anions are coordinated via the edges (cation $\cdots \mathrm{H}_{2} \mathrm{~B}$ coordination scheme) forming an isocahedron around the $\mathrm{Y}^{3+}$ cations. For the $\alpha-\mathrm{Y}\left(\mathrm{BH}_{4}\right)_{3}$ the isocahedron is somewhat distorted while it is regular for $\beta-\mathrm{Y}\left(\mathrm{BH}_{4}\right)_{3}(\mathrm{Y}-\mathrm{H}$ distance is 2.2553(3) $\AA$ at RT).

As was pointed out in the Experimental Section, $\beta$ - $\mathrm{Y}\left(\mathrm{BH}_{4}\right)_{3}$ has $P m \overline{3} m$ symmetry with $\mathrm{BH}_{4}$ groups disordered over the two positions. The short-range order of the $\mathrm{BH}_{4}$ group is presumably reducing the number of repulsive $\mathrm{H} \cdots \mathrm{H}$ contacts locally to zero, so that they exceed $2.48 \AA$. This situation is somewhat similar to the disordered cubic $\mathrm{MBH}_{4}(M=\mathrm{Na}-\mathrm{Cs})$, where the number of the repulsive $\mathrm{H} \cdots \mathrm{H}$ contacts is minimized via a local ordering of the $\mathrm{BH}_{4}$ groups. ${ }^{35}$ The periodic order of the tetrahedral $\mathrm{BH}_{4}$ groups without short $\mathrm{H} \cdots \mathrm{H}$ contacts can be achieved in $\beta$-Y $\left(\mathrm{BH}_{4}\right)_{3}$ only in the $2 \times 2 \times 2$ supercell. In the $\alpha-\mathrm{Y}\left(\mathrm{BH}_{4}\right)_{3}$ structure, $\mathrm{BH}_{4}$ ordering also induces some reorientation of the $\mathrm{BH}_{4}$ groups and distortion of the $\mathrm{YB}_{6}$ cubes. These distortions allow the lowtemperature $\alpha-\mathrm{Y}\left(\mathrm{BH}_{4}\right)_{3}$ structure to be more densely packed. The unit cell volume of $\mathrm{Y}\left(\mathrm{BH}_{4}\right)_{3}$ increases drastically on the transition from $\alpha-\mathrm{Y}\left(\mathrm{BH}_{4}\right)_{3}$ to $\beta$ - $\mathrm{Y}\left(\mathrm{BH}_{4}\right)_{3}$; thus, the high-temperature $\beta$-Y $\left(\mathrm{BH}_{4}\right)_{3}$ structure becomes much more open. This is evident from Figure 6, which shows the unit cell volumes as a function of temperature for the two phases, and reveal that $\beta-\mathrm{Y}\left(\mathrm{BH}_{4}\right)_{3}$ is 4.5 to $4.7 \%$ less dense than $\alpha-\mathrm{Y}\left(\mathrm{BH}_{4}\right)_{3}$ at all temperatures.

The structure of $\beta$-Y $\left(\mathrm{BH}_{4}\right)_{3}$ appears to be porous by observations of a large unoccupied void $\left(\sim 39 \AA^{3}\right)$ at the position $1 / 2,1 / 2,1 / 2$, with a distance from its center to the nearest atom (hydrogen) of $3.3 \AA$. It is similar in size to the void found in the low-temperature phase of $\mathrm{Mg}\left(\mathrm{BH}_{4}\right)_{2}{ }^{32}$ However, in the small unit cell of $\beta$-Y $\left(\mathrm{BH}_{4}\right)_{3}$ it occupies almost a quarter of the volume. The structure of $\alpha$ $\mathrm{Y}\left(\mathrm{BH}_{4}\right)_{3}$ is more dense, and the distance from the center of the empty void to the nearest atom (hydrogen) is approximately $2.6 \AA$; hence, the related volume of the void is much smaller $\left(\sim 11 \AA^{3}\right)$. This allows us to conclude that the high-temperature $\beta$-Y $\left(\mathrm{BH}_{4}\right)_{3}$ structure is highly porous, likely because of the directional metal $\cdots \mathrm{BH}_{4}$ bonding defining the non-densely packed architecture of this structure.

${ }^{11}$ B MAS NMR. The ${ }^{11}$ B MAS NMR spectra of the central and satellite transitions for samples of $\mathrm{LiBH}_{4}-$ $\mathrm{YCl}_{3}$ (3:1) and (4:1) (Figures 3a and 3b) include resonances from two distinct ${ }^{11} \mathrm{~B}$ sites with chemical shifts of $-17.3 \mathrm{ppm}$ and $-41.2 \mathrm{ppm}$ and somewhat different relative intensities. The resonance at $-41.2 \mathrm{ppm}$ originates from $\mathrm{LiBH}_{4}{ }^{36}$ and thus, the centerband at -17.3 ppm is assigned to the unique ${ }^{11} \mathrm{~B}$ site in $\alpha-\mathrm{Y}\left(\mathrm{BH}_{4}\right)_{3}$. Furthermore, the centerband from this phase has a shoulder at lower frequency, as most clearly observed for the $\mathrm{LiBH}_{4}-\mathrm{YCl}_{3}$ (4:1) sample (Figure 3b), which is ascribed to the small amount of $\beta-\mathrm{Y}\left(\mathrm{BH}_{4}\right)_{3}$ present in the

(35) Filinchuk, Y.; Hagemann, H. Eur. J. Inorg. Chem. 2008, 20, 31273133.

(36) Arnbjerg, L. M.; Ravnsbæk, D. B.; Filinchuk, Y.; Vang, R. T.; Cerenius, Y.; Besenbacher, F.; Jørgensen, J.-E.; Jakobsen, H. J.; Jensen, T. R. Chem. Mater. 2009, 21, 5772-5782.

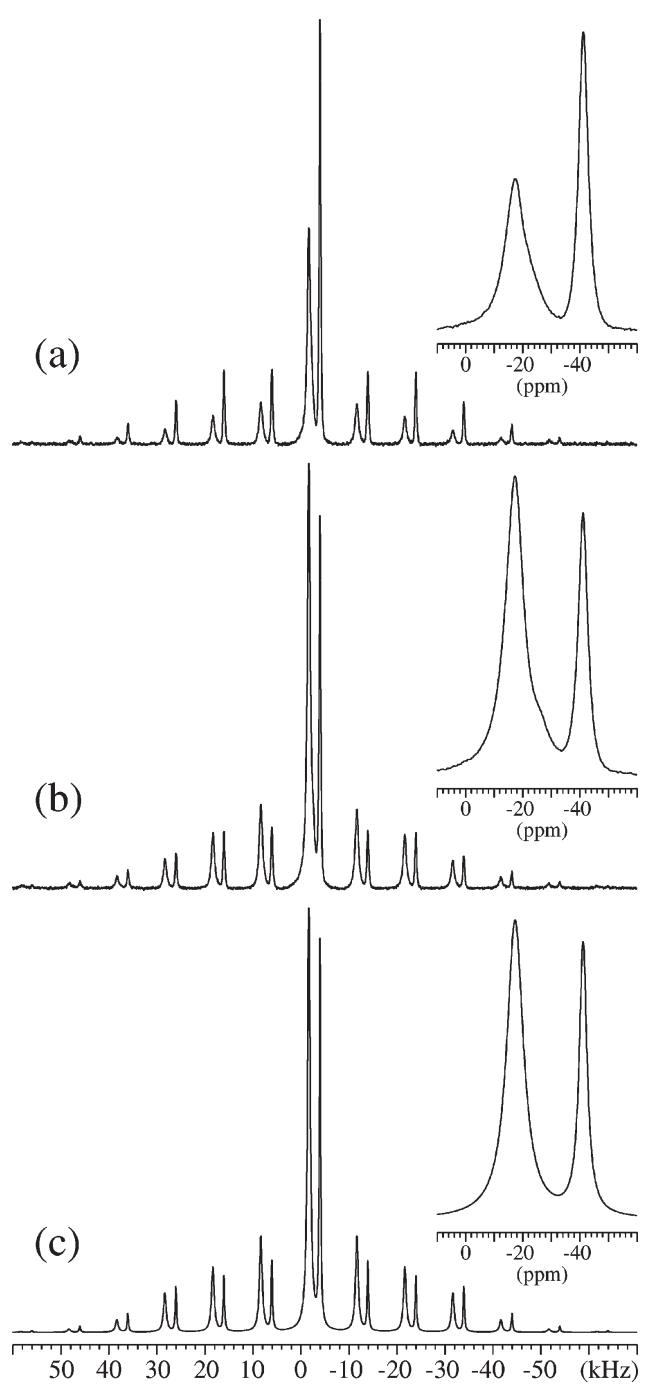

Figure 3. ${ }^{11} \mathrm{~B}$ MAS NMR spectra (7.05 T) of samples (a) $\mathrm{LiBH}_{4}-\mathrm{YCl}_{3}$ (3:1) and (b) $\mathrm{LiBH}_{4}-\mathrm{YCl}_{3}(4: 1)$, recorded with a spinning speed of $v_{\mathrm{R}}=$ $10.0 \mathrm{kHz}$, employing high-power ${ }^{1} \mathrm{H}$ decoupling during acquisition. (c) Simulated spectrum of the resonances from $\alpha-\mathrm{Y}\left(\mathrm{BH}_{4}\right)_{3}$ and $\mathrm{LiBH}_{4}$ in sample $\mathrm{LiBH}_{4}-\mathrm{YCl}_{3}(4: 1)$, employing the optimized $\delta_{\text {iso }}, C_{\mathrm{Q}}$, and $\eta_{\mathrm{Q}}$ parameters listed in the text for these two phases.

sample at ambient temperature as observed from PXD (vide supra). Spectral integration of the resonances from the central and satellite transitions gives the molar fraction of boron present as $\mathrm{LiBH}_{4}$ and $\mathrm{Y}\left(\mathrm{BH}_{4}\right)_{3}$ in the samples. For the $\mathrm{LiBH}_{4}-\mathrm{YCl}_{3}$ (3:1) sample the molar ratio $\mathrm{LiBH}_{4} /$ $\mathrm{Y}\left(\mathrm{BH}_{4}\right)_{3}$ of 1.00:0.34 is obtained, corresponding to a weight ratio of 1.00:2.05, which is in a good agreement with the weight fractions obtained by Rietveld refinement. For the $\mathrm{LiBH}_{4}-\mathrm{YCl}_{3}(4: 1)$ sample the molar ratio $\mathrm{LiBH}_{4} / \mathrm{Y}\left(\mathrm{BH}_{4}\right)_{3}$ of 1.00: 0.71 (i.e., 1.00:4.37 by weight) is determined which shows that the reaction is more complete since the sample contains a significantly higher quantity of $\mathrm{Y}\left(\mathrm{BH}_{4}\right)_{3}$ as compared to $\mathrm{LiBH}_{4}$. PXD detects only small amounts of $\mathrm{LiBH}_{4}$ in the $\mathrm{LiBH}_{4}-\mathrm{YCl}_{3}$ (3:1) sample, whereas it was not observed for the $\mathrm{LiBH}_{4}-\mathrm{YCl}_{3}$ (4:1) sample. This indicates that the excess of $\mathrm{LiBH}_{4}$ is present mainly as an X-ray amorphous phase, most likely caused by the high-energy $\mathrm{BM}$ process. Furthermore, the BM may have produced a $\mathrm{LiBH}_{4}-\mathrm{LiCl}$ solid solution, ${ }^{36}$ in which $\mathrm{BH}_{4}{ }^{-}$units are partly substituted by $\mathrm{Cl}^{-}$anions (vide infra). 


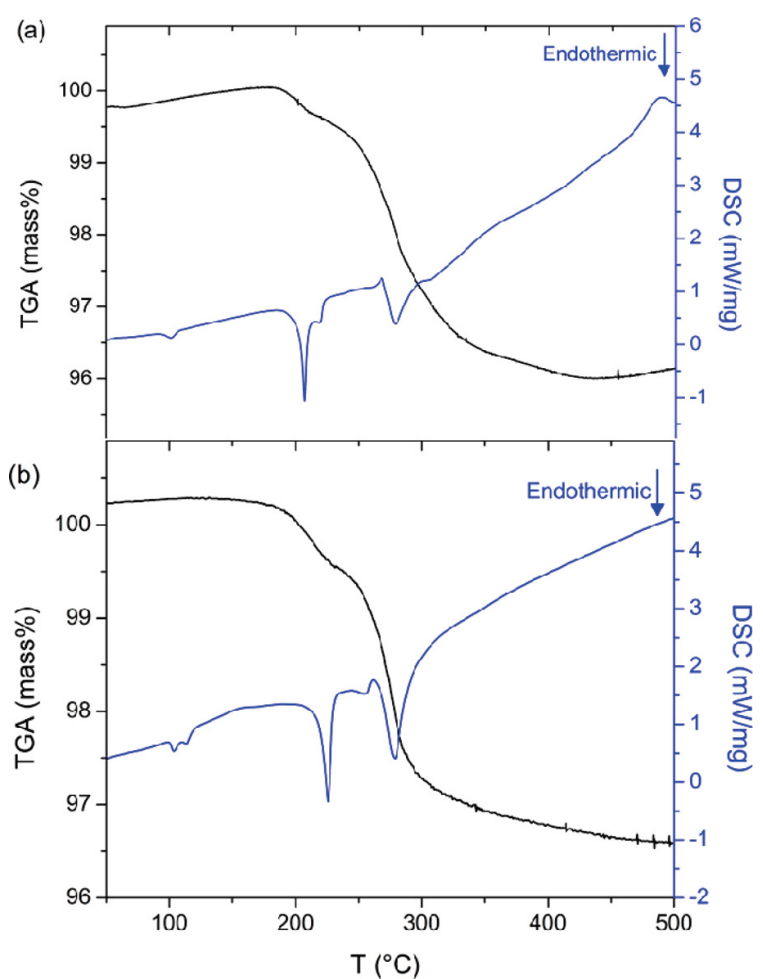

Figure 4. TGA-DSC data for samples containing $\alpha-\mathrm{Y}\left(\mathrm{BH}_{4}\right)_{3}, \mathrm{LiCl}$ and small amounts of $\beta$-Y $\left(\mathrm{BH}_{4}\right)_{3}$. (a) Ball-milled sample of $\mathrm{LiBH}_{4}-\mathrm{YCl}_{3}(4: 1)$ measured from RT to $500{ }^{\circ} \mathrm{C}, \Delta T / \Delta t=7^{\circ} \mathrm{C} / \mathrm{min}$ and (b) ball-milled sample of $\mathrm{LiBH}_{4}-\mathrm{YCl}_{3}(3: 1)$ measured from $\mathrm{RT}$ to $500^{\circ} \mathrm{C}, \Delta T / \Delta t=$ $10^{\circ} \mathrm{C} / \mathrm{min}$.

Spinning sidebands from the satellite transitions are observed over a narrow spectral range $(<100 \mathrm{kHz})$, reflecting very small ${ }^{11} \mathrm{~B}$ quadrupole couplings for both $\mathrm{Y}\left(\mathrm{BH}_{4}\right)_{3}$ and $\mathrm{LiBH}_{4}$. This is in accordance with previous observations for $\mathrm{LiBH}_{4}{ }^{36}$ and with the highly symmetric $\mathrm{BH}_{4}{ }^{-}$ion in the cubic structure of $\mathrm{Y}\left(\mathrm{BH}_{4}\right)_{3}$. The ${ }^{11} \mathrm{~B} \mathrm{MAS}$ NMR spectra can be satisfactorily simulated using two distinct resonances for $\alpha-\mathrm{Y}\left(\mathrm{BH}_{4}\right)_{3}$ and $\mathrm{LiBH}_{4}$, as illustrated by the optimized simulation (Figure $3 \mathrm{c}$ ) of the central and satellite transitions for the $\mathrm{LiBH}_{4}-\mathrm{YCl}_{3}(4: 1)$ sample. The optimization gives the parameters $\delta_{\text {iso }}=$ $-17.3 \mathrm{ppm}, C_{\mathrm{Q}}=77.4 \mathrm{kHz}, \eta_{\mathrm{Q}}=0.97$ for $\alpha-\mathrm{Y}\left(\mathrm{BH}_{4}\right)_{3}$ and $\delta_{\text {iso }}=-41.2 \mathrm{ppm}, C_{\mathrm{Q}}=90 \mathrm{kHz}, \eta_{\mathrm{Q}}=0.94$ for $\mathrm{LiBH}_{4}$. The latter values for $\mathrm{LiBH}_{4}$ are in accordance with the literature. ${ }^{36}$ A comparison of the experimental and simulated centerbands for $\mathrm{Y}\left(\mathrm{BH}_{4}\right)_{3}$ (insets Figure 3) clearly reveals the presence of the low-frequency shoulder at approximately $-26 \mathrm{ppm}$, assigned to the minor quantity of $\beta-\mathrm{Y}\left(\mathrm{BH}_{4}\right)_{3}$. Thus, the ${ }^{11} \mathrm{~B}$ chemical shifts for $\alpha$ - and $\beta$-Y $\left(\mathrm{BH}_{4}\right)_{3}$ are rather similar to those observed for LiSc$\left(\mathrm{BH}_{4}\right)_{4}\left(-23 \mathrm{ppm}^{37}\right)$ and $\mathrm{NaSc}\left(\mathrm{BH}_{4}\right)_{4}\left(-21.6 \mathrm{ppm}^{8}\right)$.

Thermal Analysis. The ball milled $\mathrm{LiBH}_{4}-\mathrm{YCl}_{3}$ samples are investigated by thermogravimetric analysis/differential scanning calorimetry (TGA/DSC), and the data are displayed in Figure 4. For the sample of molar ratio 4:1 (Figure 4a) the mass loss observed by TGA can be subdivided into two steps: one separate step between 185 and $215^{\circ} \mathrm{C}$, followed by a mass loss covering a wide

(37) Hwang, S. -J.; Bowman, R. C., Jr.; Reiter, J. W.; Rijssenbeek, J.; Soloveichik, G. L.; Zhao, J.-C.; Kabbour, H.; Ahn, C. C. J. Phys. Chem. C 2008, 112, 3164-3169. temperature range from 215 to $420{ }^{\circ} \mathrm{C}$, the latter likely composed of two or more steps. This indicates a multistep dehydrogenation process. The total observed mass loss in the temperature range 185 to $420^{\circ} \mathrm{C}$ is $4.04 \mathrm{wt} \%$, which is less than the calculated hydrogen content $(4.28 \mathrm{wt} \%$ calculated relative to the sample composition $4: 1$ ); hence, no gaseous boranes, $\left(\mathrm{BH}_{3}\right)_{n}$, appear to be lost during the decomposition. This is in agreement with previously reported TGA-DTA and quadrupole mass spectrometry (QMS) data. ${ }^{26}$

Endothermic peaks are observed by DSC at 101, 207, $219,260,278$, and $305^{\circ} \mathrm{C}$ (peak temperatures). The peak at $101{ }^{\circ} \mathrm{C}$ most likely arises from excess $\mathrm{LiBH}_{4}$ present in the sample, as this temperature corresponds to the phase transition for $\mathrm{LiBH}_{4}$ from the orthorhombic to the hexagonal high-temperature phase. ${ }^{40}$ The peak at $207{ }^{\circ} \mathrm{C}$ corresponds to the first mass loss, whereas the peaks at 260,278 , and $305^{\circ} \mathrm{C}$ are observed in the same temperature range as the second mass loss. The latter peak has a very long tail, which may reflect a small mass loss taking place from approximately 330 to $420^{\circ} \mathrm{C}$.

The TGA/DSC data for the sample $\mathrm{LiBH}_{4}-\mathrm{YCl}_{3}$ in molar ratio 3:1 (Figure $4 \mathrm{~b}$ ) is very similar to the data for the sample with molar ratio 4:1; however, small differences are observed. The mass loss is taking place in two abrupt steps in the temperature ranges from 160 to $230^{\circ} \mathrm{C}$ and 230 to $300{ }^{\circ} \mathrm{C}$, followed by a minor slow mass loss occurring from $\sim 310$ to $500{ }^{\circ} \mathrm{C}$. The observed mass loss of $4.64 \mathrm{wt} \%$ is exactly equal to the calculated hydrogen content (relative to the sample composition 3:1), which suggests that only hydrogen is released from the $3: 1$ sample. In addition to the peaks observed for the $4: 1$ sample, a small endothermic peak is observed at $113^{\circ} \mathrm{C}$, whereas the peak at $305{ }^{\circ} \mathrm{C}$ is not observed for the $3: 1$ sample in contrast to the $4: 1$ sample. The latter suggest that the decomposition pathway is composed of fewer steps for the sample of $\mathrm{LiBH}_{4}-\mathrm{YCl}_{3}$ in the molar ratio $3: 1$, which is also in agreement with the separate mass loss steps. These observations for the decomposition of the $4: 1$ and 3:1 samples will be assigned in the following.

Decomposition Mechanism for $\mathbf{Y}\left(\mathbf{B H}_{4}\right)_{3}$. Figure 5 shows in situ SR-PXD data for the sample consisting of $\mathrm{LiBH}_{4}-\mathrm{YCl}_{3}$ (4:1). In the temperature range from $\mathrm{RT}$ to $\sim 160{ }^{\circ} \mathrm{C}$, diffraction from $\mathrm{LiCl}, \alpha-\mathrm{Y}\left(\mathrm{BH}_{4}\right)_{3}$ and small amounts of $\beta-\mathrm{Y}\left(\mathrm{BH}_{4}\right)_{3}$ are present, and no significant changes in the diffracted intensities are observed. The diffracted intensity from $\alpha-\mathrm{Y}\left(\mathrm{BH}_{4}\right)_{3}$ decreases upon further heating and disappears at $\sim 180{ }^{\circ} \mathrm{C}$. In the same temperature interval an increase in the diffracted intensity from $\beta-\mathrm{Y}\left(\mathrm{BH}_{4}\right)_{3}$ is observed (inset in Figure 5). This suggests that a phase transition from $\alpha$ - to $\beta$-Y $\left(\mathrm{BH}_{4}\right)_{3}$ takes place in the temperature range 160 to $180^{\circ} \mathrm{C}$ (at a heating rate of $\left.7^{\circ} \mathrm{C} / \mathrm{min}\right) . \beta$ - $\mathrm{Y}\left(\mathrm{BH}_{4}\right)_{3}$ exists in a narrow temperature range from $\sim 180$ to $\sim 190{ }^{\circ} \mathrm{C}$ where diffraction is observed to vanish because of decomposition with a mass loss of approximately $0.5 \mathrm{wt} \%$ according to the

(38) Mosegaard, L.; Møller, B.; Jørgensen, J. E.; Bösenberg, U.; Dornheim, M.; Hanson, J. C.; Cerenius, Y.; Walker, G.; Jakobsen, H. J.; Besenbacher, F.; Jensen, T. R. J. Alloys Compd. 2007, 446-447, 301-305.

(39) Riktor, M. D.; Sørby, M. H.; Chopek, K.; Fichtner, M.; Hauback, B. C. J. Mater. Chem. 2009, 19, 2754-2759.

(40) Soulié, J. -P.; Renaudin, G.; Černý, R.; Yvon, K. J. Alloys Compd. 2002, 346, 200-205. 


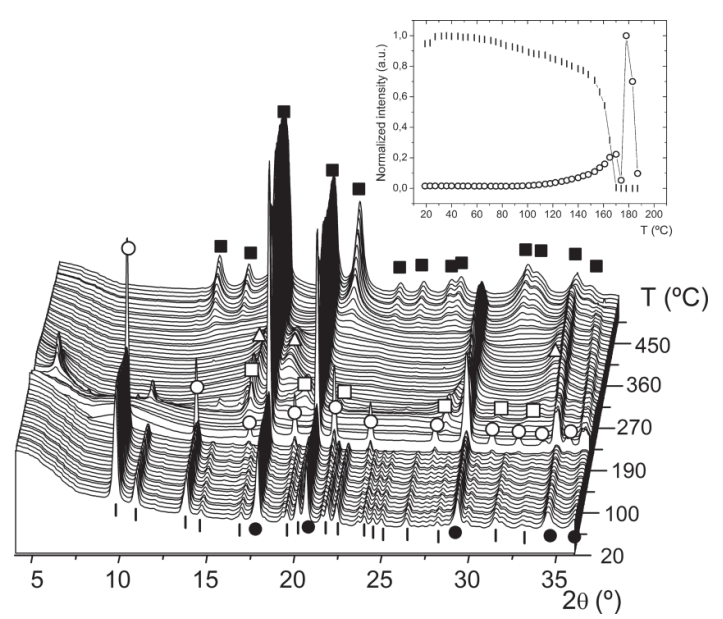

Figure 5. In situ SR-PXD data for $\mathrm{LiBH}_{4}-\mathrm{YCl}_{3}$ in molar ratio 4:1 $(\lambda=$ $0.9077 \mathrm{~A}$, RT to $\left.500{ }^{\circ} \mathrm{C}, 7^{\circ} \mathrm{C} / \mathrm{min}\right)$. Inset: Normalized integrated intensity of selected Bragg peaks from $\alpha$ - and $\beta-\mathrm{Y}\left(\mathrm{BH}_{4}\right)_{3}$ as a function of temperature. Symbols: $\mid \alpha-\mathrm{Y}\left(\mathrm{BH}_{4}\right)_{3},-\mathrm{LiCl}, \bigcirc \beta-\mathrm{Y}\left(\mathrm{BH}_{4}\right)_{3}, \square \mathrm{YH}_{3}$, $\triangle \mathrm{YH}_{2}, \mathrm{YB}_{4}$ (unmarked peaks corresponds to unidentified phases).

TGA analysis. This phase transition is not observed by DSC, although a phase transition has previously been reported by DSC measurements at $201{ }^{\circ} \mathrm{C} .{ }^{26}$ This may indeed correspond to the phase transition from the lowtemperature $\alpha-\mathrm{Y}\left(\mathrm{BH}_{4}\right)_{3}$ to the high-temperature polymorph $\beta-\mathrm{Y}\left(\mathrm{BH}_{4}\right)_{3}$, since $\mathrm{LiCl}$ was removed from the sample after BM by use of diethyl ether, ${ }^{26}$ resulting in a higher quantity of $\mathrm{Y}\left(\mathrm{BH}_{4}\right)_{3}$ implying that the peak from the phase transition is more easily resolved. Furthermore, the chemical separation may slightly alter the thermal properties of $\mathrm{Y}\left(\mathrm{BH}_{4}\right)_{3}$, which may explain the observed temperature discrepancy between the previous DSC results and the PXD data presented in this study.

In the $20-90{ }^{\circ} \mathrm{C}$ range, the linear thermal expansion coefficient is slightly lower for the $\beta$-phase $\left(1.1 \times 10^{-5} \mathrm{~K}^{-1}\right)$ than for $\alpha-\mathrm{Y}\left(\mathrm{BH}_{4}\right)_{3}\left(1.4 \times 10^{-5} \mathrm{~K}^{-1}\right)$. At higher temperatures $\left(100-160{ }^{\circ} \mathrm{C}\right)$ it increases by more than a factor of 2 for both phases, reaching $2.5 \times 10^{-5} \mathrm{~K}^{-1}$ for the $\beta$-phase and $3.1 \times 10^{-5} \mathrm{~K}^{-1}$ for $\alpha-\mathrm{Y}\left(\mathrm{BH}_{4}\right)_{3}$ (see Figure 6).

$\mathrm{YH}_{3}$ forms at $\sim 200{ }^{\circ} \mathrm{C}$ which suggests that hydrogen is released from the sample. This corresponds well with the temperature for the first mass loss observed by TGA/ DSC. As the temperature reaches $\sim 270{ }^{\circ} \mathrm{C}$ diffraction from $\mathrm{YH}_{3}$ decreases slowly and $\mathrm{YH}_{2}$ is formed. The two degrees of freedom, temperature and hydrogen content, result in that the peaks of $\mathrm{YH}_{3}$ and $\mathrm{YH}_{2}$ exhibit shifts in $2 \theta$ positions and are rather broad because of the changes in composition and due to thermal expansion.

At $\sim 380{ }^{\circ} \mathrm{C}, \mathrm{YH}_{2}$ decomposes slowly. Both observations of decomposition for $\mathrm{YH}_{3}$ and $\mathrm{YH}_{2}$ correspond to the TGA-DSC data in which mass loss and corresponding endothermic peaks are observed at these temperatures, that is, hydrogen is released in these processes. At $\sim 400{ }^{\circ} \mathrm{C}$, diffraction from $\mathrm{YB}_{4}$ slowly emerges. This compound may have formed as an amorphous phase at a lower temperature and crystallizes slowly as the temperature is increased.

Furthermore, in the temperature range from $\sim 215$ to $280{ }^{\circ} \mathrm{C}$ an unidentified compound is observed exhibiting diffraction peaks at 5.25 and $10.60^{\circ} 2 \theta$ (see Figure 5). The formation of this phase is in accord with the endo-

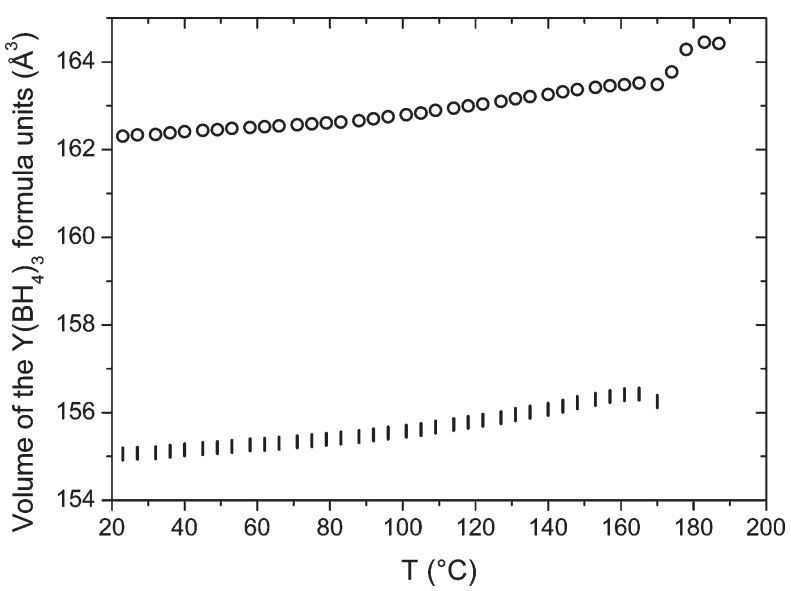

Figure 6. Volume of the $\mathrm{Y}\left(\mathrm{BH}_{4}\right)_{3}$ formula unit $(V / Z)$ for $\alpha-\mathrm{Y}\left(\mathrm{BH}_{4}\right)_{3}$ and $\beta$-Y $\left(\mathrm{BH}_{4}\right)_{3}$ phases as a function of temperature. Symbols: $\mid \alpha-\mathrm{Y}\left(\mathrm{BH}_{4}\right)_{3}$ and $\bigcirc \beta$-Y $\left(\mathrm{BH}_{4}\right)_{3}$.

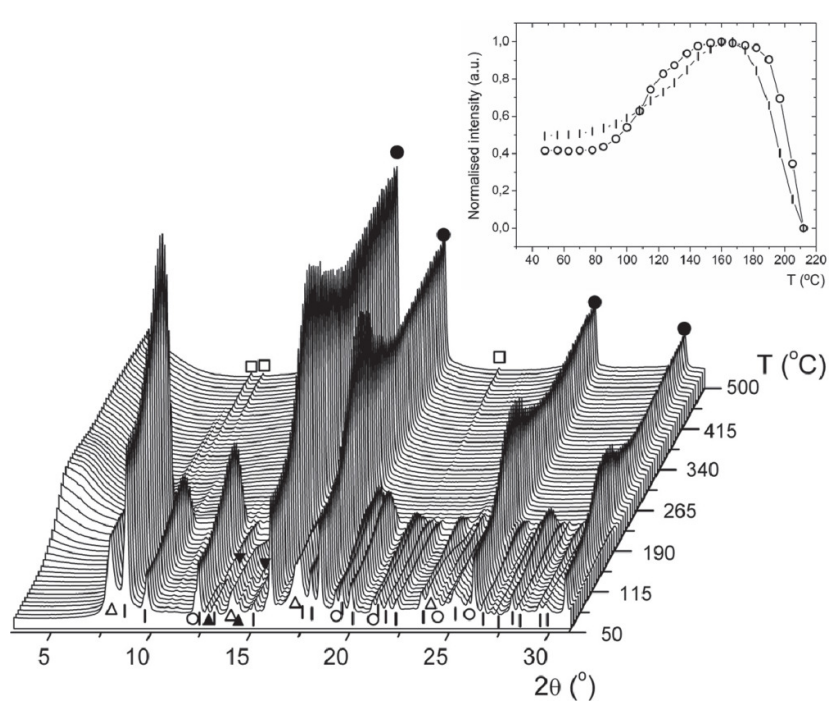

Figure 7. In situ SR-PXD data for $\mathrm{LiBH}_{4}-\mathrm{YCl}_{3}$ in molar ratio $3: 1(\lambda=$ $0.822406 \AA$, RT to $\left.500{ }^{\circ} \mathrm{C}, 4{ }^{\circ} \mathrm{C} / \mathrm{min}\right)$. Inset: Normalized integrated intensity of selected Bragg peaks from $\alpha$ - and $\beta-\mathrm{Y}\left(\mathrm{BH}_{4}\right)_{3}$ as a function of temperature. Symbols: $\mid \alpha-\mathrm{Y}\left(\mathrm{BH}_{4}\right)_{3}, \bullet \mathrm{LiCl}, \bigcirc \beta-\mathrm{Y}\left(\mathrm{BH}_{4}\right)_{3}, \triangle \mathrm{YCl}_{3}$, $\Delta$ orthorhombic $\mathrm{LiBH}_{4}, \boldsymbol{\nabla}$ hexagonal $\mathrm{LiBH}_{4}$, and $\square \mathrm{Li}_{3} \mathrm{YCl}_{6}$ (unmarked peaks correspond to unidentified phases).

thermic peak observed by DSC measurements at $219^{\circ} \mathrm{C}$, while the decomposition may contribute to the peak at $278{ }^{\circ} \mathrm{C}$, also assigned to the transformation of $\mathrm{YH}_{3}$ to $\mathrm{YH}_{2}$. This unidentified material may be a new compound in the $\mathrm{Y}-\mathrm{B}-\mathrm{H}$ system similar to other decomposition intermediate phases recently described. Decomposition of $\mathrm{LiBH}_{4}$ may lead to formation of $\mathrm{Li}_{2} \mathrm{~B}_{12} \mathrm{H}_{12}$ containing $\left[\mathrm{B}_{12} \mathrm{H}_{12}\right]^{2-}$ ions as previously observed by X-ray diffraction and solid-state NMR while decomposition of $\mathrm{Ca}\left(\mathrm{BH}_{4}\right)_{2}$ recently revealed a new material $\mathrm{CaB}_{2} \mathrm{H}_{2}$ containing $\left[\mathrm{B}_{2} \mathrm{H}_{2}\right]^{2-}$ ions. $^{37-39}$

The in situ SR-PXD data for the sample of $\mathrm{LiBH}_{4}-$ $\mathrm{YCl}_{3}$ (3:1), displayed in Figure 7, reveals a somewhat different reaction pattern. As previously mentioned, the metathesis reaction was not completed under the selected $\mathrm{BM}$ conditions, that is, diffraction from both reactants, $\mathrm{LiBH}_{4}$ and $\mathrm{YCl}_{3}$ and products $\mathrm{LiCl}, \alpha-\mathrm{Y}\left(\mathrm{BH}_{4}\right)_{3}$, and $\beta-\mathrm{Y}\left(\mathrm{BH}_{4}\right)_{3}$ are observed. At $\sim 100{ }^{\circ} \mathrm{C}$ the phase 
transformation of the orthorhombic to hexagonal $\mathrm{LiBH}_{4}$ is observed. ${ }^{40}$ As the temperature reaches $\sim 90^{\circ} \mathrm{C}$, the amount of $\mathrm{LiBH}_{4}$ and $\mathrm{YCl}_{3}$ decreases; meanwhile an increase in the diffracted intensity from $\mathrm{LiCl}, \alpha-\mathrm{Y}\left(\mathrm{BH}_{4}\right)_{3}$, and $\beta$-Y $\left(\mathrm{BH}_{4}\right)_{3}$ is observed, that is, the metathesis reaction 1 continues during heating of the sample. The temperature at which this process is initiated may be in accord with the additional DSC peak observed at $113^{\circ} \mathrm{C}$ for the $3: 1$ sample. It is interesting to note that $\beta-\mathrm{Y}\left(\mathrm{BH}_{4}\right)_{3}$ forms at a higher rate than $\alpha-\mathrm{Y}\left(\mathrm{BH}_{4}\right)_{3}$ during this process (inset Figure 7). Furthermore, $\beta$ - $\mathrm{Y}\left(\mathrm{BH}_{4}\right)_{3}$ seems to decompose at a temperature $\sim 10^{\circ} \mathrm{C}$ higher as compared to $\alpha-\mathrm{Y}\left(\mathrm{BH}_{4}\right)_{3}$ form, which is in accordance with the observation for the $4: 1$ sample.

At $\sim 200{ }^{\circ} \mathrm{C}$ diffraction from both $\alpha-\mathrm{Y}\left(\mathrm{BH}_{4}\right)_{3}$ and $\beta$-Y $\left(\mathrm{BH}_{4}\right)_{3}$ vanish, which correspond to the observations for the 4:1 sample (Figure 5) and the TGA/DSC data (Figure 4b). However, the phase transition $\alpha$ - to $\beta$-Y$\left(\mathrm{BH}_{4}\right)_{3}$ at $\sim 180{ }^{\circ} \mathrm{C}$, and the formation of the decomposition products $\mathrm{YH}_{3}, \mathrm{YH}_{2}, \mathrm{Y}-\mathrm{B}-\mathrm{H}$, and $\mathrm{YB}_{4}$ are not observed in the SR-PXD data. This may be due to different SR-PXD sample conditions; the 4:1 sample was mounted in a sample holder designed to withstand high pressure, that is, the released hydrogen during the decomposition provide increasing hydrogen pressure, which alters the decomposition pathway drastically. On the other hand, the $3: 1$ sample was mounted in a glass capillary, which may have leaked the hydrogen released from the sample.

Second, for both samples, $3: 1$ and 4:1, a solid solution of $\mathrm{LiBH}_{4}-\mathrm{LiCl}$ may form during $\mathrm{BM}$ where $10-20 \%$ of LiCl could have dissolved in $\mathrm{LiBH}_{4}$ by anion substitution in the $\mathrm{LiBH}_{4}$ lattice forming $\mathrm{Li}\left(\mathrm{BH}_{4}\right)_{1-x} \mathrm{Cl}_{x}$. ${ }^{36}$ This is known to have a stabilizing effect on $\mathrm{LiBH}_{4}$, and it may also retard the formation of $\mathrm{Y}\left(\mathrm{BH}_{4}\right)_{3}$ during the metathesis reaction 1. Apparently, excess $\mathrm{LiBH}_{4}$ is needed for a relatively fast formation of $\mathrm{Y}\left(\mathrm{BH}_{4}\right)_{3}$ as observed for the 4:1 composition where all $\mathrm{YCl}_{3}$ is consumed.

For the composition $3: 1$, some $\mathrm{YCl}_{3}$ remains in the sample after $\mathrm{BM}$. Clearly, $\mathrm{YCl}_{3}$ extracts $\mathrm{LiBH}_{4}$ from the $\mathrm{LiBH}_{4}-\mathrm{LiCl}$ solid solution at elevated temperatures $\left(T>85^{\circ} \mathrm{C}\right)$ and forms $\mathrm{Y}\left(\mathrm{BH}_{4}\right)_{3}$ according to the reaction Scheme 1. Yttrium borohydride decomposes and forms apparently an amorphous $\mathrm{Y}-\mathrm{B}-\mathrm{H}$ containing phase which may contribute to the significant increase in the background intensity at $2 \theta>\sim 7^{\circ}$.

Two unidentified compounds are observed to crystallize after the decomposition of $\mathrm{Y}\left(\mathrm{BH}_{4}\right)_{3}$, which are different from those observed in the $(4: 1)$ sample. A compound observed in the temperature range $\sim 190$ to $235^{\circ} \mathrm{C}$ may have a composition similar to $\mathrm{Y}\left(\mathrm{BH}_{4}\right) \mathrm{Cl}_{2}$ or $\mathrm{Y}\left(\mathrm{BH}_{4}\right)_{2} \mathrm{Cl}$ previously described. ${ }^{41,42}$ Anion substitution may also have a stabilizing effect in $\mathrm{Y}\left(\mathrm{BH}_{4}\right)_{3}$, resulting in decomposition at higher temperatures. The second phase could be a $\mathrm{Y}-\mathrm{B}-\mathrm{Cl}$ containing decomposition product. At $\sim 375{ }^{\circ} \mathrm{C}$ a small amount of $\mathrm{Li}_{3} \mathrm{YCl}_{6}$ forms, likely in an addition reaction between unreacted $\mathrm{YCl}_{3}$ and $\mathrm{LiCl}$, as shown in eq 2 .

$$
\mathrm{YCl}_{3}+3 \mathrm{LiCl} \rightarrow \mathrm{Li}_{3} \mathrm{YCl}_{6}
$$

Additional information about the $\mathrm{Y}\left(\mathrm{BH}_{4}\right)_{3}$ decomposition product is obtained from the ${ }^{11} \mathrm{~B}$ MAS NMR

(41) Rossmanith, K. Monatsh. Chem. 1961, 92, 768-776.

(42) Marks, T, J.; Kolb, J. R. Chem. Rev. 1977, 77, 263-293.

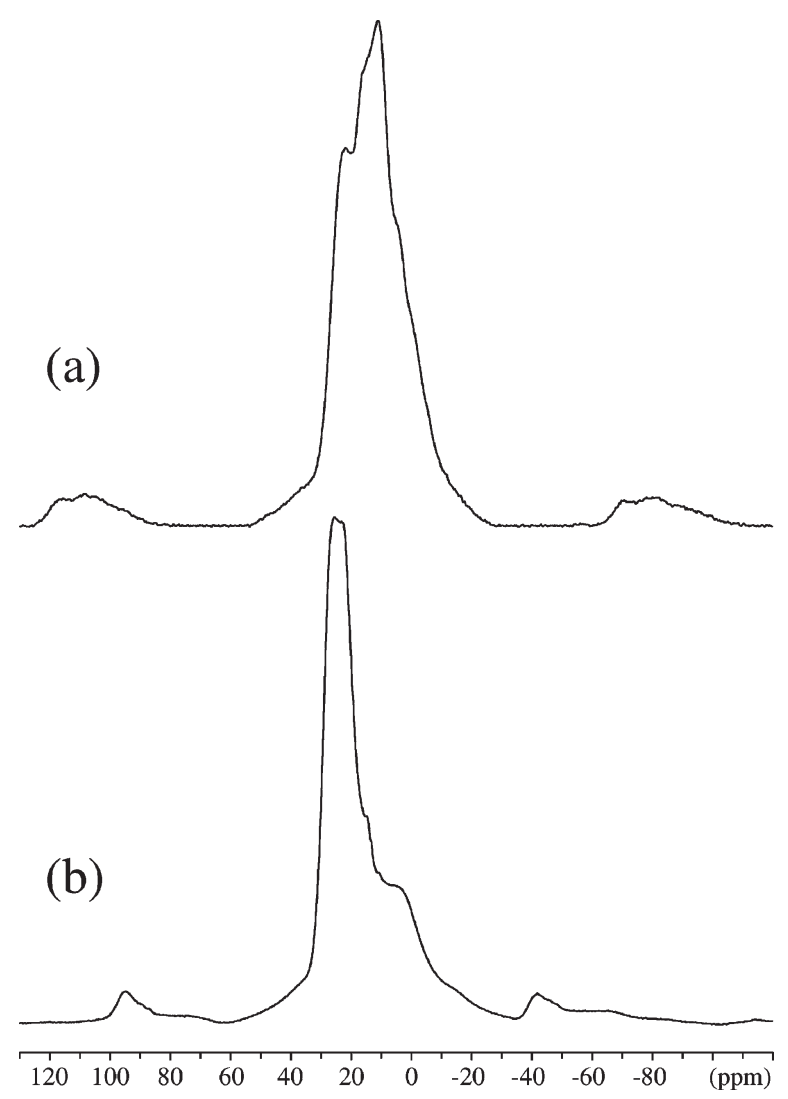

Figure 8. ${ }^{11} \mathrm{~B}$ MAS NMR spectra of the $\mathrm{LiBH}_{4}-\mathrm{YCl}_{3}$ (4:1) sample, heated from RT to $500{ }^{\circ} \mathrm{C}\left(7^{\circ} \mathrm{C} / \mathrm{min}\right.$. $)$ and stored at this temperature for $90 \mathrm{~min}$, recorded at (a) $9.39 \mathrm{~T}$ and (b) $14.09 \mathrm{~T}$ using spinning speeds of $v_{\mathrm{R}}=12.0 \mathrm{kHz}$ and $\nu_{\mathrm{R}}=13.0 \mathrm{kHz}$, respectively.

spectra of the material resulting from heating a bulk sample of $\mathrm{LiBH}_{4}-\mathrm{YCl}_{3}(4: 1)$ in an argon atmosphere to $500{ }^{\circ} \mathrm{C}\left(7^{\circ} \mathrm{C} / \mathrm{min}\right.$. $)$ and storing it at this temperature for 90 min. (i.e., a heat treatment similar to the in situ SR-PXD experiment, considering the larger amount of sample). The signal intensities, observed in the ${ }^{11} \mathrm{~B}$ MAS NMR spectra at two magnetic field strengths (Figure 8), reveal that the decomposition product contains a significant quantity of boron. The absence of narrow spinning sidebands from the satellite transitions indicates that a major part of the boron is present in less-crystalline phases and exhibits quite large ${ }^{11} \mathrm{~B}$ quadrupole couplings. The latter is also apparent from the width of the central transitions (Figure 8), which is approximately $60 \mathrm{ppm}$ at $14.09 \mathrm{~T}$. PXD measurement of the same sample shows the presence of $\mathrm{YB}_{4}$ as the only crystalline boron-containing phase. The ${ }^{11} \mathrm{~B}$ quadrupole coupling parameters for the three different boron sites in $\mathrm{YB}_{4}$ has earlier been reported by static-powder ${ }^{11} \mathrm{~B}$ NMR and found to be in accordance with the corresponding ${ }^{11} \mathrm{~B}$ electric-field gradients, obtained by density functional theory calculations. ${ }^{43}$ These data shows that $\mathrm{YB}_{4}$ exhibits rather small quadrupole couplings, that is, $C_{\mathrm{Q}}=1.03$, 1.40 , and $1.03 \mathrm{MHz}$ for $\mathrm{B}(1), \mathrm{B}(2)$, and $\mathrm{B}(3)$, respectively. This will result in rather narrow resonances for the ${ }^{11} \mathrm{~B}$ central transitions at 9.39 and $14.09 \mathrm{~T}$ and thus, $\mathrm{YB}_{4}$ may only account for the narrow peaks at 25.8 and $22.7 \mathrm{ppm}$ in the 14.09 $\mathrm{T}$ spectrum (Figure $8 \mathrm{~b}$ ) and in the range

(43) Jäger, B.; Paluch, S.; Wolf, W.; Herzig, P.; Zogal, O. J.; Shitsevalova, N.; Paderno, Y. J. Alloys Compd. 2004, 383, 232-238. 
22.3-11.1 ppm at 9.39 T (Figure 8a) and thereby not the dominating part of the central-transition intensity in the ${ }^{11}$ B MAS NMR spectra. The chemical shifts for the boron sites in the decomposition product is expected to be above $\sim 20 \mathrm{ppm}$, considering the strong quadrupolar broadening, which imply that borate or borohydride species are not present in the sample. Thus, we ascribe the main part of the intensity in the ${ }^{11} \mathrm{~B}$ MAS NMR spectra to less-crystalline boron phase(s) including multiple ${ }^{11} \mathrm{~B}$ sites, and potentially containing yttrium. We note that an ${ }^{11} \mathrm{~B}$ MQMAS NMR spectrum (14.09 T) of the decomposition product only resolved two resonances, most likely arising from the small quadrupole couplings in the $\mathrm{YB}_{4}$ phase.

\section{Conclusion}

The mechanism for the thermal decomposition of $\alpha$ - and $\beta$-Y $\left(\mathrm{BH}_{4}\right)_{3}$ is studied by in situ synchrotron radiation PXD, ${ }^{11} \mathrm{~B}$ MAS NMR spectroscopy, and thermal analysis (TGA/DSC). A new high-temperature polymorph of $\mathrm{Y}\left(\mathrm{BH}_{4}\right)_{3}$, denoted $\beta$ $\mathrm{Y}\left(\mathrm{BH}_{4}\right)_{3}$, is discovered, which has lower density and higher crystal symmetry of the cubic crystal structure as compared to the known phase $\alpha-\mathrm{Y}\left(\mathrm{BH}_{4}\right)_{3}$. We have demonstrated that a moderate hydrogen pressure may facilitate stabilization of boron as a metal boride in the solid dehydrogenated phase. These results are very promising for attaining the reversible hydrogen storage in $\mathrm{Y}\left(\mathrm{BH}_{4}\right)_{3}$. Yttrium borohydride has an $\alpha$ - to $\beta$-Y $\left(\mathrm{BH}_{4}\right)_{3}$ phase transition at $\sim 180{ }^{\circ} \mathrm{C}, \beta-\mathrm{Y}\left(\mathrm{BH}_{4}\right)_{3}$ decomposes at $\sim 190{ }^{\circ} \mathrm{C}$ to $\mathrm{YH}_{3}$, which transforms to $\mathrm{YH}_{2}$ at
$270{ }^{\circ} \mathrm{C}$. An unidentified phase is observed in the temperature range 215 to $280^{\circ} \mathrm{C}$, which may be a new $\mathrm{Y}-\mathrm{B}-\mathrm{H}$ containing decomposition product. The final decomposition products are $\mathrm{YB}_{4}$ as well as amorphous boron containing compounds. Thermogravimetric measurements suggest that hydrogen solely is released during the decomposition in the temperature range 185 to $420^{\circ} \mathrm{C}$, which is in strong contrast to $\mathrm{LiBH}_{4}$ that decomposes at $T>400{ }^{\circ} \mathrm{C}$. The ${ }^{11} \mathrm{~B}$ MAS NMR further underlines that boron was retained in the solid phase during decomposition. This study reveals that the stability and decomposition reactions mechanism can be tailored by the metal in the crystal structure and the gas atmosphere.

Acknowledgment. The authors are grateful to the SwissNorwegian Beamlines, ESRF for the provision of inhouse beam time. We are also grateful to the staff of beamline I911-5, MAX-Lab for experimental support. We thank the Danish Natural Science Research Councils for funding to the Instrument Centre for Solid-State NMR Spectroscopy, the research program DanScatt, and the Danish Strategical Research Council's Center for Energy Materials (CEM) and to Center for Materials Crystallography (CMC) funded by The Danish National Research Foundation. R.C. thanks the Swiss National Science Foundation for the support.

Supporting Information Available: X-ray crystallographic files in CIF format. This material is available free of charge via the Internet at http://pubs.acs.org. 